\title{
The Impact of Corporate Social Responsibility on Oil and Gas Firms' Access to Finance
}

\author{
Abdelmajid Hmaittane \\ Ibn Zohr University \\ Bouchra M'Zali \\ Université du Québec à Montréal \\ Mohamed Mnasri \\ HEC Montréal \\ Rachid Ghilal \\ Université du Québec à Rimouski
}

This paper examines whether corporate social responsibility (CSR) affects the access to financing. We test our predictions using a sample of 1467 firm-year observations belonging to US oil and gas industry and covering the period from 1991 to 2012. The findings indicate that CSR, measured by the aggregated CSR score, does not affect firm's access to capital. Nevertheless, when disaggregated CSR scores (strengths and concerns) are used, an asymmetric effect of CSR on firm's access to capital is shown. While CSR strengths activities negatively affect firm's access to external financing, those activities that reduce social concerns enhance this access.

Keywords: corporate social responsibility, access to finance, financial constraints, oil and gas industry

\section{INTRODUCTION}

Over the last two decades, capital markets witnessed a significant raise in social and environmental issues awareness. The steady and continuous growth of socially responsible investing (SRI) illustrates clearly such trend. According to the forum for sustainable and responsible investing (US SIF), the value of SRI assets has expanded to $\$ 12.0$ trillion in the United States, which represents 26 percent, or 1 in 4 dollars, of the $\$ 46.6$ trillion in total assets under professional management in 2018. ${ }^{1}$ This remarkable increase of investors' interest in the way companies behave toward their stakeholders, raises the question of whether corporate social responsibility affects firm's access to external financing. The goal of this paper is to examine this link in the context of US firms operating in the oil and gas industry.

The context of the oil and gas industry is particularly interesting for investigation since, from an investor perspective, firms' CSR behavior might induce a high ambivalent perception. On the one hand, oil and gas firms can be perceived as socially and environmentally "irresponsible" because their operations have many potential negative environmental and social consequences such as oil spills, natural 
gas emissions and conflicts with local communities (Frynas, 2009). On the other hand, the same firms can be perceived as "responsible" due to their CSR achievements and contributions to the society at large. For instance, they made important environmental improvements including the decrease in the number and the volume of oil spills ${ }^{2}$, the reduction of gas emissions, the investment in renewable energy alternatives and the development of community programs (in education, health, agriculture, transport, construction, etc.) in developing countries (Frynas, 2009). Toward such ambivalent perception, it is important to examine how investors react to oil and gas firms' CSR commitment through the study of the impact on firm's financing constraints.

Based on the theoretical literature, two competing views, respectively risk mitigation and overinvestment, can explain how firm's commitment to CSR can affect its access to financing. Under the risk mitigation view, firm's high (low) CSR engagement will reduce (enhance) its risk trough a decrease (increase) in its asymmetric information and agency costs, its exposure to risk and or an increase (decrease) in its investor base. Such risk reduction (increase) translates in more (less) access to financing. Therefore, the risk mitigation view implies that CSR activities are expected to positively affect the firm' $\mathrm{s}$ access to financing.

Under the overinvestment view, the investors perceive CSR activities as a waste of firm's scarce resources (Goss and Roberts, 2011). They will require higher risk premium for holding stocks of firms involved in CSR initiatives. Therefore, the more (less) likely a firm is committed to social and environmental activities the less (more) its access to financing is. Consequently, CSR initiatives are expected to negatively affect the firm' s access to financing.

We test the predictions of the two theoretical views using a sample of 1,467 firm-year observations belonging to US oil and gas industry and covering the period from 1991 to 2012. The obtained results show that CSR, measured by the aggregated CSR score, does not affect firm's access to capital. However, when this score is disaggregated to social strengths and concerns an important asymmetric effect is revealed. While CSR activities that increase firm's social strengths negatively affect access to external financing, those activities that reduce CSR concerns improve this access.

This study makes different contributions to the literature. First, it contributes to the large CSR literature by giving evidence of an asymmetric effect of CSR on firm's access to capital in the context of oil and gas industry. Whereas CSR actions that increase firm' social strengths negatively affect access to external financing, those actions that target social concerns improve this access. Second, this paper extends the growing body of studies that examine investor' perceptions of firm's CSR activities (e.g., Sharfman and Fernando, 2008; Goss and Roberts, 2011; El Ghoul et al., 2011; Jo and Na, 2012; Bouslah et al., 2013; Cheng et al., 2014). ${ }^{3}$ Third, by focusing on oil and gas firms we also extend those scarce empirical studies that investigate how CSR commitment affect corporate financial performance in the context of the controversial industry sectors (Cai et al., 2012, and Jo and Na, 2012).

This article is organized as follows. The next section discusses the theoretical literature that can explain how firm's commitment to CSR can affect its access to financing and develops research hypotheses. In the third section, we describe our data and define our model and variables. Section 4 and 5 provide respectively our empirical results and some robustness tests. We conclude in the sixth section.

\section{LITERATURE REVIEW AND HYPOTHESES DEVELOPMENT}

Under the perfect capital markets assumption, the Modigliani and Miller theorem implies that firm's investment and financing decisions are independent (Modigliani and Miller, 1958). In imperfect markets, however, due to asymmetric information and agency costs (in Myers and Majluf, 1984; and Jensen and Meckling, 1976, respectively) external capital is more expensive than internal capital. Such financing costs wedge constrains corporate investments in that it could impediment firm's ability to finance all positive NPV projects (Campello et al., 2009) and to sustain higher growth rates (Binks and Ennew, 1996; Carpenter and Petersen, 2002). ${ }^{4}$ Therefore, any factor that alleviates a firm's financial constraints can lead to more efficient investment decisions and higher firm growth rates. In the following, we provide 
two competing theoretical views, respectively the risk mitigation and the overinvestment, that can explain how firm's commitment to CSR can affect its access to financing.

According to the risk mitigation view, firm's commitment to CSR activities reduces its risk and therefore improves its access to external financing. In support of this view, three arguments can be provided namely the asymmetric information, the firm's exposure to risk and the investor base.

First, high (low) information asymmetry between stockholders and firm's managers implies high (low) agency costs needed to gather appropriate information and to check if managers act in the interest of investors. As firm's CSR commitment may signal the quality of management to stockholders (Akpinar et al., 2008), it decreases the agency costs associated with monitoring and auditing activities. Therefore, high (low) CSR may decrease (increase) the required risk premium for holding the company's stock and as such increase (decrease) firm's access to financing. In line with this argument, Hong and Kacperczyk (2009) find that sin stocks, receive less coverage from financial analysts and have higher expected returns than do stocks of otherwise comparable characteristics.

Second, by initiating CSR activities, a firm reduces its probability to face significant future cash outflows related to social and/or environmental misconducts such as environment pollution and poor working conditions. Consequently, by avoiding such future cash outflows, firm's CSR commitment will reduce firm's exposure to risk (Godfrey, 2005; El Ghoul et al., 2011; McGuire et al., 1988) and thereby will improve its access to capital (Waddock and Graves, 1997).

Different studies give support to this argument such as Spicer (1978) who shows that companies with better pollution control records tend to have lower total and systematic risks. Also, Feldman et al. (1997) find that investors perceive firms with higher environmental performance as less risky and Karpoff et al. (2005) provide evidence that the size of the stock price reaction to environmental violations is related to regulatory and legal penalties.

Third, although finance theory suggests that investors should hold the diversified market portfolio, different studies show that they do not. For instance, Merton (1987) theoretical model predicts that investors invest only in stocks they are informed about. Therefore, the investor base differs across stocks and those stocks with smaller shareholder bases, and thereby with limited risk sharing opportunities, should yield higher returns. Subsequent studies give support to these results such as those of Heinkel et al. (2001) and Hong and Kacperczyk (2009). Overall, under this argument, firms with no or less CSR commitment are more likely to be avoided by social conscious investors and therefore their shareholder base would be smaller than that of firms with high CSR involvement.

In sum, in the context of the risk mitigation view and based thee above arguments, firm's high (low) CSR commitment will increase (decrease) firms' access to financing. Consequently, our first hypothesis is as follows:

\section{Hypothesis 1: CSR activities positively affect the firm's access to financing.}

Under the overinvestment view, the investors consider CSR activities as a waste of firm's scarce resources (Goss and Roberts, 2011) and consequently as destroying their own wealth. They will require higher risk premium for holding stocks of firms involved in CSR initiatives. Therefore, the more (less) likely a firm is committed to social and environmental activities the less (more) its access to financing is.

One incentive for managers to overinvest is to obtain private benefits of building their own personal reputation as good citizens (Barnea and Rubin, 2010). Another incentive is that by gaining the support of social and environmental activists, managers reduce the probability of their replacement in the future (Cespa and Cestone, 2007). Also, they can behave in an opportunistic way. They can reduce corporate social investments in good times so as to increase their own personal profits and can increase them in bad times in order to justify disappointing financial results (Preston and O'Bannon, 1997).

Hence, based on the overinvestment view, higher (lower) firm's CSR commitment is expected to be associated with less (high) access to financing. Accordingly, our second hypothesis is:

Hypothesis 2: CSR activities negatively affect the firm's access to financing. 


\section{DATA AND METHODOLOGY}

\section{Data}

To test our hypotheses, we merged social and financial data coming respectively from MSCI ESG STATS ((formerly KLD Research \& Analytics, Inc.) and COMPUSTAT databases. We restrict our sample to firms belonging to the oil and gas industry based on the SIC classification. Therefore, we follow Jo and $\mathrm{Na}$ (2012) and use all firms with SIC codes of 1300, 1310 to 1339, 1370 to 1382, 1389, 2900 to 2912 and 2990-2999. The final sample is an unbalanced panel of 1467 firm-year observations over the period from 1991 to 2012.

\section{Methodology}

Regression Model

Our baseline model directly links CSR score to the financial constraints measure as follows:

$$
F C_{i, t}=\alpha_{0}+\alpha_{1} C S R_{i, t-1}+\alpha_{2} \operatorname{Size}_{i, t}+\varepsilon_{i, t}
$$

where FCi,t stands for financial constraints of firm i in year t, CSRi,t-1 is the corporate social responsibility score of firm $\mathrm{i}$ in year $\mathrm{t}-1$ and Sizei,t is the size of firm $\mathrm{i}$ in year $\mathrm{t}$ measured by the natural logarithm of the market value of equity. Financial constraint and corporate social responsibility score are defined below. All of the continuous variables used in this study are winsorized at the first and the 99th percentile and all the regressions control for firms and years fixed effects.

Firm's Access to Financing

For our dependant variable, the firm's access to financing, we follow the corporate finance literature (e.g., Lamont et al. 2001; Almeida et al., 2004; Bakke and Whited, 2010; Cheng et al., 2014) and use Kaplan and Zingales (1997) index. We constructed $K Z$ for a given firm i in a given year $t$ as follows:

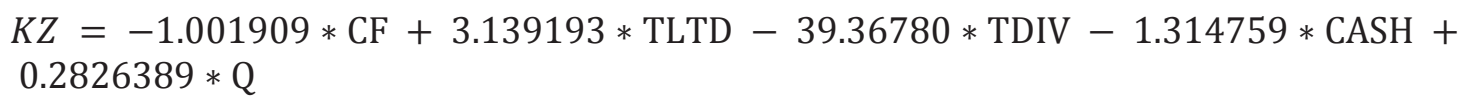

where CF is the ratio of cash flow to book assets; TLTD is the ratio of total long-term debt to book assets; TDIV is the ratio of total dividends to book assets; CASH is the ratio of the stock of cash to book assets; and $\mathrm{Q}$ is the market to book ratio, whose numerator is defined as book assets minus book equity minus balance sheet deferred taxes plus the market value of equity, and the denominator is equal to book assets.

\section{Corporate Social Responsibility Scores}

We obtain CSR scores from the MSCI ESG STATS. This database provides, on an annual basis, binary data (1 or zero) for U.S. firms. Each firm is rated on seven qualitative dimensions (both strength and concern scores) and six exclusionary screens (with only concern scores). The qualitative dimensions are community, diversity, employee relations, environment, product, human rights, and corporate governance. The exclusionary screens are alcohol, gambling, firearms, military, nuclear power, and tobacco.

We follow previous studies (e.g., Harjoto and Jo, 2008; Oikonomou et al., 2012; Bouslah et al., 2013) and compute for each firm-year observation the average strengths (STR_index) and the average concerns (CON_index) scores of the seven KLD dimensions. The average strengths STR_index (concerns CON_index) score is the total number of strengths (concerns) divided by the total number of possible strengths (concerns), for each firm-year observation. Additionally, we compute an aggregate social score, CSR_index, which represents the difference between the average strengths (STR_index) and the average concerns (CON_index) scores.

Following prior studies (e.g. Slater and Dixon-Fowler, 2009; Manner, 2010; Cheng et al., 2014), we use the aggregated CSR score (CSR_index) which enables us to compare our results to theirs. However, 
such a single measure of CSR might be problematic since it merges together fundamentally different and perhaps conflicting underlying mechanisms: "doing good" reflected in KLD strengths and "avoiding to do harm" reflected in KLD concerns (Cheng et al., 2014).

According to Mattingly and Berman (2006), CSR strengths and concerns are both empirically and conceptually distinct constructs. They do not covary in opposing directions and therefore should not be combined in research because such combination of nonconvergent, or independent variables, can often mask an underlying link between variables. Thus, in addition to the aggregated score, we consider the separate scores of CSR strengths and concerns in our analyses.

\section{EMPIRICAL RESULTS}

\section{Summary Statistics}

Table 1 reports summary statistics for our key variables. It shows that the mean (median) of the aggregated social score CSR_index, which represents the net of average social strengths over the average social concerns, is negative with a value of $-0.034(-0.048)$. This indicates that the average social concerns exceed that of social strengths. This is supported by the individual measures of social strengths and concerns. Respectively, the mean (median) for social concerns is $0.093(0.069)$ and for social strengths is 0.058 (0.024). Also, Table 1 shows that the mean (median) of the indicator of firm's access to financing, which is the Kaplan and Zingales index variable, is 0.857 (0.863) and ranges from -7.4270 to 8.702.

\section{TABLE 1}

\section{SUMMARY STATISTICS}

\begin{tabular}{ccccccc}
\hline Variable & $\mathrm{N}$ & Mean & Median & Std dev & Minimum & Maximum \\
\hline KZ & 1467 & 0.857 & 0.863 & 1.292 & -7.427 & 8.702 \\
CSR_index & 1467 & -0.034 & -0.048 & 0.113 & -0.464 & 0.583 \\
STR_index & 1467 & 0.058 & 0.024 & 0.098 & 0 & 0.692 \\
CON_index & 1467 & 0.093 & 0.069 & 0.088 & 0 & 0.545 \\
Size & 1467 & 7.759 & 7.753 & 1.686 & 1.008 & 10.592 \\
\hline
\end{tabular}

Notes: This table presents descriptive statistics for the sample over the period from 1991 to 2012. Mean, median, standard deviation, minimum and maximum values are reported. $\mathrm{KZ}$ is the Kaplan and Zingales index constructed for a given firm i in a given year $t$ using equation 2 as reported in methodology section. STR index: the average strengths score is the total number of strengths divided by the total number of possible strengths, for each firm-year observation. CON_index: the average concerns score is the total number of concerns divided by the total number of possible concerns, for each firm-year observation. CSR_index represents the difference between the average strengths (STR_index) and the average concerns (CON_index) scores for each firm-year observation. Size: firm' size measured as the natural logarithm of total assets; All the continuous variables are winsorized at the first and the $99^{\text {th }}$ percentile.

In Table 2, the correlations between our main variables are provided. The three social scores (CSR_index, STR_index and CON_index) are significantly and positively correlated (respectively at the $10 \%, 5 \%$ and $1 \%$ level) to $\mathrm{KZ}$ index. While high access to financing (low $\mathrm{KZ}$ index) is associated with low CSR_index and STR_index scores, it is also associated with low social concerns (CON_index). Therefore, firm's social strengths actions are correlated with low access to financing but those activities reducing social concerns are associated with high access to capital. 
TABLE 2

MEAN COMPARISON ANALYSIS

\begin{tabular}{lccc}
\hline & \multicolumn{3}{c}{ KZ index } \\
\cline { 2 - 4 } CSR measure & High CSR (1) & Low CSR (2) & Difference (2)-(1) \\
\hline CSR_index & 0.927 & 0.799 & $-0.128^{* *}$ \\
STR_index & 0.988 & 0.656 & $-0.332^{* * *}$ \\
CON_index & 1.107 & 0.746 & $-0.361^{* * *}$ \\
\hline
\end{tabular}

Notes: This table provides means and mean difference comparisons of our key variable KZ index. It gives means and mean differences for high and low CSR firms. The three CSR scores, CSR_index, STR_index and CON_index, are used. High versus low CSR score is defined around the median for each given year. KZ is the Kaplan and Zingales index constructed for a given firm $\mathrm{i}$ in a given year $\mathrm{t}$ using equation 2 as reported in methodology section. All the continuous variables are winsorized at the first and the $99^{\text {th }}$ percentile. ${ }^{* * *},{ }^{* *},{ }^{*}$ indicate significance at the $1 \%, 5 \%$ and $10 \%$ levels, respectively.

Table 3 presents the KZ index means for firms in subsamples with high and low social scores. For each year, a firm is assigned to the subsample of high (low) social score when its CSR score in that year is above (below) the sample median. The last column of the table provides the mean differences between the two subsamples.

The three differences are negative and significant. Firms with low social scores (CSR_index, STR_index and CON_index) have higher access to capital. In line with earlier findings in Table 2 , these results show that firm's social strengths activities are associated with low access to financing which supports our second hypothesis (overinvestment). In contrast, those activities reducing social concerns are associated with high access to financing and thereby giving support to the first hypothesis (risk mitigation).

TABLE 3

CORRELATION MATRIX

\begin{tabular}{lcccccc}
\hline Variables & & $(1)$ & $(2)$ & $(3)$ & $(4)$ & $(5)$ \\
\hline KZ & $(1)$ & 1.000 & & & & \\
CSR_index & $(2)$ & $0.024^{*}$ & 1.000 & & & \\
STR_index & $(3)$ & $0.094^{* *}$ & $0.662 * * *$ & 1.000 & & \\
CON_index & $(4)$ & $0.247^{* * *}$ & $-0.542^{* * *}$ & $0.271^{* *}$ & 1.000 & \\
Size & $(5)$ & $-0.267 * * *$ & -0.006 & $0.445^{* * *}$ & $0.505^{* * *}$ & 1.000 \\
\hline
\end{tabular}

Notes: This table reports the Pearson correlation coefficients among our main variables for the 1467 observations from 1991 to 2012. See Table 1 for variable definitions. All the continuous variables are winsorized at the first and the $99^{\text {th }}$ percentile. ${ }^{* * *},{ }^{* *},{ }^{*}$ indicate significance at the $1 \%, 5 \%$ and $10 \%$ levels, respectively.

\section{Fixed Effects OLS Regressions}

This study examines the effect of firm's CSR engagement on its access to external financing. In Table 4, we present the results of the regression of four models where CSR scores are regressed on firm's KZ index controlling for firm size, years and firms fixed effects.

The results of the first model show that the estimated coefficient associated with the aggregated social score CSR_index is insignificant. Thus, CSR_index score does not impact firm's access to external capital. In the second model, we use CSR strengths (STR_index) as a firm' CSR score. The STR_index' 
coefficient is positive and significant at 5\% level. Therefore, high STR_index score increases firm' KZ index and thereby reduces firm's access to financing.

The results of the regression of the third model, which uses CSR concerns (CON_index) score, are reported in the fourth column. The coefficient associated with this CSR score is positive and significant at 5\% level implying that firm' actions that increase (reduce) CSR concerns reduce (increase) firm's access to external financing. In the fourth and last model, we jointly regress CSR strengths (STR_index) and CSR concerns (CON_index) scores on KZ index. The obtained CSR coefficients for the two scores are positive and significant at 5\% level. Thus, as in model 2 and 3, these results show that firm' social commitment that increases (reduces) STR index (CON_index) increases (decreases) firm' KZ index and consequently reduces (enhances) firm's access to financing.

Overall, we get three results. First, when we use the aggregated CSR score, social engagement has no effect on firm's access to finance. This result supports the finding of El Ghoul et al. (2011) and Goss and Roberts (2011). While El Ghoul et al. (2011) find that firm's participation to controversial business areas of alcohol, gambling, firearms and military has no impact on firm's implied cost of equity capital, Goss and Roberts show that the involvement in controversial activities related to nuclear, military, alcohol and gambling has no effect on firm's cost of bank loans.

Second, when CSR strengths score is used, CSR activities decrease firm's access to capital as expected in the over-investment hypothesis. This finding gives support to earlier results in the literature. El Ghoul et al. (2011) find that firm's participation to tobacco and nuclear activities increases its cost of equity. Also, Goss and Roberts (2011) study gives evidence that firm's contribution to tobacco activities increase firm's cost of private credit loans.

Third, when CSR concerns score is used, the effect is positive on KZ index. This implies that social actions targeting CSR concerns (lowering CON_index score) reduce KZ index and improve firm's access to capital. This last result supports the expectation in the first hypothesis (risk mitigation) and is consistent with Goss and Roberts (2011) findings which show that firms with social responsibility concerns pay between 7 and 18 basis points more than firms that are more responsible.

\section{TABLE 4}

FIXED EFFECTS OLS REGRESSION RESULTS

\begin{tabular}{lcccc}
\hline & $(1)$ & $(2)$ & $(3)$ & $(4)$ \\
\hline Lagged CSR_index & 0.025 & & & \\
Lagged STR_index & & $0.598^{* *}$ & & $0.642^{* *}$ \\
Lagged CON_index & & & $0.929^{* *}$ & $0.977^{* *}$ \\
Size & $-0.288^{* * *}$ & $-0.282^{* * *}$ & $-0.288^{* * *}$ & $-0.284^{* * *}$ \\
Constant & $2.542^{* * *}$ & $2.563^{* * *}$ & $2.532^{* * *}$ & $2.555^{* * *}$ \\
& & & & \\
Observations & 1,467 & 1,467 & 1,467 & 1,467 \\
R-squared & 0.665 & 0.666 & 0.666 & 0.667 \\
Firms \&Years FE & YES & YES & YES & YES \\
\hline
\end{tabular}

Notes: This table reports firms and years fixed effects OLS regressions results for our sample. The dependant variable KZ is Kaplan and Zingales index constructed for a given firm i in a given year t using equation 2 as reported in methodology section. STR_index: the average strengths score is the total number of strengths divided by the total number of possible strengths, for each firm-year observation. CON_index: the average concerns score is the total number of concerns divided by the total number of possible concerns, for each firm-year observation. CSR index represents the difference between the average strengths (STR index) and the average concerns $(\mathrm{CON}$ _index) scores for each firm-year observation. SIZE: firm' size measured as the natural logarithm of total assets; All the continuous variables are winsorized at the first and the $99^{\text {th }}$ percentile. ${ }^{* * *},{ }^{* *},{ }^{*}$ indicate significance at the $1 \%, 5 \%$ and $10 \%$ levels, respectively. 


\section{ROBUSTNESS CHECKS}

In this section, we subject our findings in Table 4 to different robustness checks. We control for potential endogeneity issue using subsamples analyses and instrumental variable regressions and we use an alternative measure of our key variable of access to financing.

\section{Reverse Causality}

The fixed effects OLS results reported in Table 4 may suffer from an endogeneity problem making the obtained coefficients biased and inconsistent. This can be the case if there is a reverse causality between firm' CSR score and its access to financing. In such context, firms with higher access to capital might invest in more CSR activities and achieve better CSR score (El Ghoul et al., 2011; Hong et al., 2011). The underlying assumption to this argument is that CSR initiatives are a form of a 'luxury good' that firms can afford only when they face no or very low financial constraints (Cheng et al., 2014). Accordingly, one would expect the relation between CSR and access to financing to be significant (insignificant) for firms with higher (lower) access to capital. Firms with lower access to financing are more likely to allocate any additional financial resources to fulfill their non-discretionary investments and expenditures rather than to use them to luxury goods.

Based on this rational and following Cheng et al. (2014), we perform subsample analyses to overcome this potential reverse causality problem. We assign all firms in our sample into two subsamples based on the level of access to financing (i.e., the KZ Index). The firm's level of Kaplan and Zingales index is defined as a dummy variable $K Z H(K Z L)$ that equals to 1 if firm's $\mathrm{KZ}$ index is above (below) the median for the given year and equals to 0 , otherwise.

We re-run the four models as in Table 4, interacting the CSR score with the two dummy variables $K Z H$ and KZL. The obtained results are presented in Table 5.

In model (1) where the aggregated social score CSR_index is used, both regression coefficients are insignificant. In model (2), (3) and (4) where STR_index and CON_index are used all interaction coefficients are significant. In contrast to the luxury good argument prediction, it is not only the interaction coefficient when a firm has low KZ index (high access to finance) which is positive and significant but also that of firms with high $\mathrm{KZ}$ index (low access to finance). Therefore, the earlier results presented so far in Table 4 are unlikely to suffer from a reverse causality issue. 
TABLE 5

FIXED EFFECTS REGRESSIONS RESULTS CONTROLLING FOR THE REVERSE CAUSALITY

\begin{tabular}{lcccc}
\hline & $(1)$ & $(2)$ & $(3)$ & $(4)$ \\
\hline Lagged CSR_index* KZH & -0.603 & & & \\
Lagged CSR_index* KZL & 0.249 & & & $0.679^{*}$ \\
Lagged STR_index* KZH & & $0.965^{*}$ & & $0.714^{* *}$ \\
Lagged STR_index* KZL & & $0.515^{*}$ & & $1.781^{* * *}$ \\
Lagged CON_index* KZH & & & $1.678^{* * *}$ & $0.493^{*}$ \\
Lagged CON_index* KZL & & & $0.467^{*}$ & $-0.296^{* * *}$ \\
Size & $-0.223^{* * *}$ & $-0.291^{* * *}$ & $-0.297^{* * *}$ & $2.402^{* * *}$ \\
Constant & $2.491^{* * *}$ & $2.536^{* * *}$ & $2.384^{* * *}$ & \\
& & & & 1,231 \\
Observations & 1,231 & 1,231 & 1,231 & 0.669 \\
R-squared & 0.666 & 0.666 & 0.668 & YES \\
Firms \& Years FE & YES & YES & YES & \\
\hline
\end{tabular}

Notes: This table reports firms and years fixed effects OLS regressions results when firms are differentiated based on their level of access to financing (low versus high KZ). The dependant variable KZ is Kaplan and Zingales index constructed for a given firm $\mathrm{i}$ in a given year $\mathrm{t}$ using equation 2 as reported in methodology section. The firm's level of Kaplan and Zingales index is defined as a dummy variable $K Z H(K Z L)$ that equals to 1 if firm's $\mathrm{KZ}$ index is above (below) the median for the given year and equals to 0, otherwise. STR index: the average strengths score is the total number of strengths divided by the total number of possible strengths, for each firm-year observation. CON_index: the average concerns score is the total number of concerns divided by the total number of possible concerns, for each firm-year observation. CSR_index represents the difference between the average strengths (STR_index) and the average concerns (CON_index) scores for each firm-year observation. SIZE: firm' size measured as the natural logarithm of total assets; All the continuous variables are winsorized at the first and the $99^{\text {th }}$ percentile. ${ }^{* * *},{ }^{* *}$, * indicate significance at the $1 \%, 5 \%$ and $10 \%$ levels, respectively.

\section{Instrumental Variable Regressions}

Another way to overcome any potential endogeneity problem between firm's social and environmental commitment and its access to financing is to instrument CSR variable and use two-stage least squares estimation for the four models estimated in Table 4. We follow past studies (e.g., Goss and Roberts, 2011) and use as instruments: the average industry CSR score, the lagged firm' CSR scores and a dummy variable reflecting whether the state in which the firm operates voted for the democratic candidate in presidential elections. The findings of the two-stage least squares regressions are reported in Table 6. The obtained findings for our three CSR scores are qualitatively similar to those reported in Table 4 and consequently our results still hold. 
TABLE 6

INSTRUMENTAL VARIABLE REGRESSIONS

\begin{tabular}{lcccc}
\hline & $(1)$ & $(2)$ & $(3)$ & $(4)$ \\
\hline Lagged CSR_index & 0.022 & & & $1.302^{*}$ \\
Lagged STR_index & & $1.118^{*}$ & & $1.375^{* *}$ \\
Lagged CON_index & & & $1.301^{* *}$ & $-0.204^{* * *}$ \\
Size & $-0.240^{* * *}$ & $-0.271^{* * *}$ & $-0.311^{* * *}$ & $2.644^{* * *}$ \\
Constant & $2.760^{* * *}$ & $2.939^{* * *}$ & $3.089^{* * *}$ & \\
& & & & 1,230 \\
Observations & 1,242 & 1,242 & 1,242 & 0.137 \\
R-squared & 0.131 & 0.120 & 0.072 & YES \\
Firms \&Years FE & YES & YES & YES & $4.887^{* *}$ \\
Durbin (score) chi2 test & $3.128^{*}$ & $6.17^{* *}$ & $26.60^{* * *}$ & $4.886^{* *}$ \\
Wu-Hausman F test & $3.126^{*}$ & $6.18^{* *}$ & $27.10^{* * *}$ & \\
\hline
\end{tabular}

Notes: This table reports results from instrumental variable regressions for our sample. Models are estimated via two-stage least squares to instrument CSR variable. The dependant variable KZ is Kaplan and Zingales index constructed for a given firm $\mathrm{i}$ in a given year $\mathrm{t}$ using equation 2 as reported in methodology section. STR index: the average strengths score is the total number of strengths divided by the total number of possible strengths, for each firm-year observation. CON_index: the average concerns score is the total number of concerns divided by the total number of possible concerns, for each firm-year observation. CSR index represents the difference between the average strengths (STR_index) and the average concerns (CON_index) scores for each firm-year observation. SIZE: firm' size measured as the natural logarithm of total assets; All the continuous variables are winsorized at the first and the $99^{\text {th }}$ percentile. ${ }^{* * *},{ }^{* *},{ }^{*}$ indicate significance at the $1 \%, 5 \%$ and $10 \%$ levels, respectively.

\section{Alternative Measure of Firm's Access to Financing}

Given the lack of consensus on how to identify financially constrained firms (and therefore the level of access to financing), we use Whited and $\mathrm{Wu}$ index (2006) as an alternative measure. It is computed using the empirical equation (13) in Whited and $\mathrm{Wu}$ (2006). For each sampled firm $i$ at year $t$, WW is given by:

WW Index $=-0.091 \mathrm{CF}-0.062 \mathrm{DIVPOS}+0.021 \mathrm{TLTD}-0.044 \mathrm{LNTA}+0.102 \mathrm{ISG}-0.035 \mathrm{SG}$

where CF is the ratio of cash and short-term investments to total assets; DIVPOS is a binary indicator equal to 1 if the firm pays cash dividends and 0 otherwise; TLTD is the ratio of the long-term debt to total assets; LNTA is the natural log of total assets; ISG is the sales growth of the firm's industry; and SG is the firm's sales growth.

The firm-year fixed effects regressions are performed using WW Index instead of KZ index and the findings are reported in Table 7. All the obtained regression coefficients for the three CSR scores are qualitatively similar to those reported in Table 4 . Therefore, all our earlier results in Table 4 still hold.

Additionally, as an alternative measure to the above $\mathrm{KZ}$ index (Equation 2), we follow Cheng et al. (2014) and compute an equally weighted KZ index where the five accounting variables are assigned equal weights. The obtained and un-tabulated results are similar to our findings in Table 4. Hence, all our inferences still hold. 


\section{TABLE 7 \\ FIXED EFFECTS REGRESSIONS RESULTS WITH ALTERNATIVE FINANCIAL CONSTRAINTS INDICATOR}

\begin{tabular}{lcccc}
\hline & $(1)$ & $(2)$ & $(3)$ & $(4)$ \\
\hline Lagged CSR_index & $0.051^{*}$ & & & $0.048^{* * *}$ \\
Lagged STR_index & & $0.0506^{* * *}$ & & $0.056^{* *}$ \\
Lagged CON_index & & & $0.059^{* *}$ & $-0.020^{* * *}$ \\
Size & $-0.020^{* * *}$ & $-0.019^{* * *}$ & $-0.020^{* * *}$ & $0.042^{*}$ \\
Constant & $0.042^{*}$ & $0.041^{*}$ & $0.042^{*}$ & \\
& & & & 1,467 \\
Observations & 1,467 & 1,467 & 1,467 & 0.277 \\
R-squared & 0.274 & 0.275 & 0.252 & YES \\
Firms \& Years FE & YES & YES & YES & YES
\end{tabular}

Notes: This table reports firms and years fixed effects OLS regressions results for our sample. The dependant variable Whited and Wu index (2006). This index is constructed for a given firm i in a given year $\mathrm{t}$ using equation 3 . STR index: the average strengths score is the total number of strengths divided by the total number of possible strengths, for each firm-year observation. CON_index: the average concerns score is the total number of concerns divided by the total number of possible concerns, for each firm-year observation. CSR index represents the difference between the average strengths (STR_index) and the average concerns (CON_index) scores for each firmyear observation. SIZE: firm' size measured as the natural logarithm of total assets; All the continuous variables are winsorized at the first and the $99^{\text {th }}$ percentile. ${ }^{* * *},{ }^{* *},{ }^{*}$ indicate significance at the $1 \%, 5 \%$ and $10 \%$ levels, respectively.

\section{CONCLUSION}

This study examines whether CSR commitment affects firm's access to financing in the context of US oil and gas industry. Based on two theoretical views, respectively the risk mitigation and the overinvestment, CSR activities are expected to increase or to decrease firm's access to external capital. These two hypotheses are tested using a U.S. sample of 1467 firm-year observations belonging to oil and gas industry and covering the period from 1991 to 2012.

The findings show that CSR does not impact firm's access to capital when an aggregated CSR score is used. However, when this score is disaggregated to social strengths and concerns, an important asymmetric effect of CSR on firm's access to capital is revealed. While CSR activities that increase firm' social strengths negatively affect access to external financing, those activities that reduce social concerns improve this access.

These findings have two important practical implications. First, they should increase managers' confidence and incentives, in oil and gas industry, to pursue activities that reduce CSR concerns rather than those that increase CSR strengths. They can undertake socially and environmentally worthy actions while improving firm's access to external capital. Second, policymakers can encourage managers to initiate CSR actions that focus on reducing social concerns through tax incentives.

Although, our results were subjected to a battery of robustness tests, our work could have some limitations that are left for future research. For instance, by relying on aggregated measures of CSR, we are probably missing important information that can help explain variations in the access to financing. Thus, future research could extend this work by considering the seven different KLD dimensions (both strengths and concerns). 


\section{ENDNOTES}

1. This represents an increase of more than 18 -fold and a compound annual growth rate of 13.6 percent from 1995 to 2018.

2. The number of large oil spills (above 700 tonnes) caused by oil tankers and other vessels has dramatically decreased from 25.2 spills per year in the period 1970-1979 to 3.6 spills per year in the period 2000-2007 (Frynas, 2009).

3. The closest paper to ours is that of Cheng et al. (2014). While this paper investigates the link between CSR and access to finance using aggregated measures of CSR (from ASSET4 database) and an international sample, we rely on disaggregated measures (strengths and concerns KLD scores) for firms in the US and belonging to a unique industry (oil and gas).

4. According to Lamont et al. (2001), this inability to raise the needed funds might be due to credit constraints or inability to borrow or issue equity, dependence on bank loans, or illiquidity of assets.

\section{REFERENCES}

Akpinar, A., Jiang, Y., Gomes-Mejia, L. R., Berrone, P., \& Walls, J. L. (2008). Strategic Use of CSR as A Signal for Good Management. IE Business School Working Paper, WP08-25.

Almeida H., Campello, M., \& Weisbach, M. S. (2004). The cash flow sensitivity of cash. Journal of Finance, 59, 1777-1804.

Bakke T. E., \& Whited, T. M. (2010). Which firms follow the market? An analysis of corporate investment decisions. Review of Financial Studies, 23(5), 1941-1980.

Barnea, A., \& Rubin, A. (2010). Corporate social responsibility as a conflict between shareholders. Journal of Business Ethics, 97, 71-86.

Binks, M., \& Ennew, C. (1996). Growing firms and the credit constraint. Small Business Economics, 8(1), $17-25$.

Bouslah, K., Kryzanowski, L., \& M'zali, B. (2013). The impact of the dimensions of social performance on firm risk. Journal of Banking \& Finance, 37(4), 1258-1273.

Cai, Y., Jo, H., \& Pan, C. (2012). Doing Well While Doing Bad? CSR in controversial industry sectors. Journal of Business Ethics, 108, 467-480.

Campello, M., Graham, J.R., \& Harvey, C. R. (2009). The Real Effects of Financial Constraints: Evidence from a Financial Crisis. NBER Working Papers 15552, National Bureau of Economic Research, Inc.

Carpenter, R., \& Petersen, B. (2002). Is the growth of small firms constrained by internal finance? Review of Economics \& Statistics, 84(2), 298 - 309.

Cespa, G., \& Cestone, G. (2007). Corporate social responsibility and managerial entrenchment. Journal of Economics and Management Strategy, 16, 741-771.

Cheng, B., Ioannou I., \& Serafeim G. (2014). Corporate social responsibility and access to finance. Strategic Management Journal, 35(1), 1-23.

El Ghoul, S., Guedhami, O., Kwok, C., \& Mishra, D. (2011). Does corporate social responsibility affect the cost of capital? Journal of Banking \& Finance, 35(9), 2388-2406.

Feldman, J., Soyka, P., \& Ameer, P. (1997). Does improving a firm's environmental management system and environmental performance result in a higher stock price? Journal of Investing, 6, 87-97.

Frynas, J. G. (2009). Corporate social responsibility in the oil and gas sector. The Journal of World Energy Law \& Business, 2(3), 178-195.

Godfrey, P. C. (2005). The relationship between corporate philanthropy and shareholder wealth: A risk management perspective. Academy of Management Review, 30, 777-798.

Goss, A., \& Roberts, G. S. (2011). The impact of corporate social responsibility on the cost of bank loans. Journal \& Banking and Finance, 35, 1794-1810.

Harjoto, M. A., \& Jo, H. (2008). Corporate social responsibility and operating performance. Journal of the Academy of Business and Economics, 8, 59-71. 
Heinkel, R., Kraus, A., \& Zechner, J. (2001). The effect of green investment on corporate behaviour. Journal of Financial and Quantitative Analysis, 36, 431-449.

Hong, H., \& Kacperczyk, M. (2009). The price of sin: The effects of social norms on markets. Journal of Financial Economics, 93, 15-36.

Jensen, M. C., \& Meckling, W. H. (1976). Theory of the firm: Managerial behavior, agency costs and ownership structure. Journal of Financial Economics, 3, 305-360.

Jo, H., \& Na, H. (2012). Does CSR reduce firm risk? Evidence from controversial industry Sectors. Journal of Business Ethics, 110, 441-456.

Kaplan, S. N., \& Zingales, L. (1997). Do investment-cash flow sensitivities provide useful measures of financing constraints? Quarterly Journal of Economics, 112, 169-215.

Karpoff, J. M., Lott, J. R., \& Wehrly, E. W. (2005). The Reputational Penalties for Environmental Violations: Empirical Evidence. Journal of Law and Economics, 48, 653-675.

Lamont, O., Polk, C., \& Saa-Requejo, J. (2001). Financial constraints and stock returns. Review of Financial Studies, 14, 529-54.

Manner, M. H. (2010). The impact of CEO characteristics on corporate social performance. Journal of Business Ethics, 93(1), 53-72.

Mattingly J. E., \& Berman S.L. (2006). Measurement of corporate social action discovering taxonomy in the Kinder Lydenburg Domini ratings data. Business \& Society, 45(1), 20-46.

McGuire, J., Sundgren, A., \& Schneeweis, T. (1988). Corporate social responsibility and firm financial performance. Academy of Management Journal, 31(4), 854-72.

Merton, R. C. (1987). A simple model of capital market equilibrium with incomplete information. Journal of Finance, 42, 483-510.

Modigliani, F., \& Miller, H. (1958). The cost of capital, corporation finance, and the theory of investment. American Economic Review, 48, 261-297.

Myers, S. C., \& Majluf, N. S. (1984). Corporate financing and investment decisions when firms have information that investors do not have. Journal of Financial Economics, 13, 187-221.

Oikonomou, I., Brooks, C., \& Pavelin, S. (2012). The impact of corporate social performance on financial risk and utility: a longitudinal analysis. Financial Management, 41, 483-515.

Preston, L. E., \& O'Bannon, D. P. (1997). The Corporate Social-Financial Performance Relationship: A Typology and Analysis. Business and Society, 36, 419-429.

Sharfman, M. P., \& Fernando, C. S. (2008). Environmental risk management and the cost of capital. Strategic Management Journal, 29, 569-592.

Slater, D. J., \& Dixon-Fowler, H. R. (2009). CEO international assignment experience and corporate social performance. Journal of Business Ethics, 89(3), 473-489.

Spicer, B. H. (1978). Investors, corporate social performance and information disclosure: An empirical study. Accounting Review, 53(1), 94-111.

US SIF Foundation. (2018). Report on US Sustainable, Responsible and Impact Investing Trends 2018. Retrieved from https://www.ussif.org/files/Trends/Trends\%202018\%20executive\%20summary\%20FINAL.pdf

Waddock, S. A, \& Graves, S. B. (1997). The Corporate Social Performance-Financial Performance Link. Strategic Management Journal, 18(4), 303-319.

Whited, T., \& Wu, G. (2006). Financial constraints risk. Review of Financial Studies, 19, 531-559. 